\title{
Progesterone Receptor Positive by Immunohistochemistry Less than 1 Percent
}

National Cancer Institute

\section{Source}

National Cancer Institute. Progesterone Receptor Positive by Immunohistochemistry

Less than 1 Percent. NCI Thesaurus. Code C141447.

An immunohistochemical staining finding indicating that less than 1 percent of the cells in a tissue sample are expressing progesterone receptor. 